\title{
Territories of Contested Womanhood: Pussyhats, the Pachamama, and Embodying Resistance in the Era of Hashtag Feminism
}

\author{
Kellie Cavagnaro ${ }^{1 *}$, Jamie E. Shenton ${ }^{2}$ \\ 1 Vanderbilt University, Nashville, TN, USA \\ ${ }^{2}$ Centre College, Danville, KY, USA \\ *Corresponding Author: kellie.cavagnaro@vanderbilt.edu \\ Citation: Cavagnaro, K. and Shenton, J. E. (2019). Territories of Contested Womanhood: Pussyhats, the \\ Pachamama, and Embodying Resistance in the Era of Hashtag Feminism, Journal of Cultural Analysis and \\ Social Change, 4(1), 04. https://doi.org/10.20897/jcasc/5847
}

Published: July 19, 2019

\begin{abstract}
In response to a recent surge of openly misogynistic political discourses at the highest levels of government, a vibrant wave of hashtag feminism across the Americas evidences women's widespread concerns over their bodily and territorial rights. Engaging Twitter and Facebook as digital archives-of-the-present, in conjunction with ethnographic interviews and surveys conducted in Peru and in the United States, we analyze protest symbols in two high-profile women's rights movements: the United States \#WomensMarch and the Peruvian \#NiUnaMenos March. For Native women in both movements, the land grabs perpetrated by state and corporate actors factored as heavily into their resistance motivations as did their concerns over bodily rights and reproductive justice, which were the central concerns of non-Native women respondents. In the United States, the majority of protesters used the pussyhat as an organizing principle to react against politicians' allusions to the physical abuse of women and their policy-driven threats to reproductive choice; meanwhile, some Native women donned the warbonnet scarf to recognize their intersectional oppressions under Donald Trump. In the Peruvian context, women across the nation took to city streets with blood red paint dripping down their thighs to provoke social memory of a recent era of forced sterilizations under Alberto Fujimori. In the Andean highlands, Aymara and Quechua women invoked the Pachamama, or Earth Mother, as a vibrant ally to aid in their battle against threats to their bodily sovereignty and the ongoing destruction of indigenous landscapes. Within these two hashtag movements, we find a pattern of mainstream communications that emphasize body as territory, while indigenous protest symbols focus not only on who is being grabbed-but where.
\end{abstract}

Keywords: gender, media ecology, indigeneity, reproductive justice, land rights

\section{INTRODUCTION}

Over the past three years, a surge of openly misogynistic political discourses has reverberated through various media platforms across the Americas, with recent notorious controversies including the battle over the nomination of now Supreme Court Justice Brett Kavanaugh, the hotly contested election of Brazil's new President Jair Bolsonaro, and the continued effects of the 2016 presidential campaigns of Donald Trump in the United States and Keiko Fujimori in Peru. Hashtags have multiplied in the wake of these events, their pithiness cutting to the heart of widespread outrage: \#BelieveWomen; \#MyPussyGrabsBack; \#WomensMarch; \#NiUnaMenos; \#StopKavanaugh; \#EleNão; \#MeToo. 
Ours is a multi-sited comparison of two case studies examining high profile women's marches that organized under the hashtag movements \#WomensMarch and \#NiUnaMenos. In the United States context, surrounding the \#WomensMarch, the majority of protesters used the pussyhat as an organizing principle to react against politicians' allusions to the physical abuse of women and their policy-driven threats to reproductive choice; meanwhile, some Native women donned what was called the warbonnet scarf to recognize their intersectional oppressions under Donald Trump as both their bodies and their lands were put up for 'grabs.' In the Peruvian context, during the \#NiUnaMenos March, women across the nation took to city streets with blood red paint dripping down their thighs to provoke social memory of a recent era of forced sterilizations under Alberto Fujimori, in a visceral protest against the (later unsuccessful) presidential bid of his daughter, Keiko Fujimori. In the Andean highlands, Aymara and Quechua women invoked the Pachamama, a sentient earth goddess, as a vibrant ally to aid in their battle against threats to their bodily sovereignty and the ongoing destruction of indigenous landscapes that is exacerbated by state policy.

Within these two case studies, we find a pattern of protest communications that emphasize body as territory for both Native and non-Native-identifying women, with Native women waging a two-front defense of their territorial or ancestral lands, as well. We find that for Native women across movements, the land grabs perpetrated by state and corporate actors factored as heavily into their hashtag feminism as did their concerns over bodily rights and reproductive justice, which were the two central concerns of white women respondents. The two-front war being fought by Native women was expressed in their particular choices of protest symbols, which conveyed dual meanings about Native women's racialized and gendered social positioning.

Shenton analyzed the United States context, considering both the warbonnet scarf and the pussyhat, one of the more prominent symbols of the Women's March 2017, by scouring online newspapers and blogs as well as social media for coverage of the pussyhat, while paying close attention to Native women's experience of the Women's March. She also administered an open-ended online survey using a general call through social media; there were 78 respondents, most of whom self-identified as white.

Cavagnaro conducted the Peruvian case study, combining her participant observation at \#NiUnaMenos protests in Puno, Peru with semi-structured interviewing of a dozen Aymara feminists and media activists in the field, followed by analysis of localized social media communications related to the \#NiUnaMenos hashtag movement at multiple sites of the multi-city march, with a focus on Puno, Lima and Arequipa.

We find that while women across ethnicities emphasized their body as territory, the resistance efforts of Native women, in particular, and regardless of their cultural context or urban/rural residency, communicated an embodied relation to the landscape that emphasized their interrelation of these two forms of sovereignty-land rights and bodily sovereignty.

\section{THEORIZING BODY AS TERRITORY}

Scholars have noted the striking connection between violence against bodies and violence against lands with the link often being a gendered one. Political scientist Jocelyn Boryczka (2017) describes the colonized vagina as the claiming, occupation, and/or brutalization of the vagina by all manner of forces. The phrase 'colonized vagina' enfolds discourses of power and embodiment and asks us to consider at once the appropriation, control, and possession of an intimate space by those other than the person with the vagina. Indigenous peoples, like Native women in the United States, have had to deal with such appropriation, control, and possession of their lands and bodies across generations of kinship and social memory:

The colonized vagina (...) links pussy grabs to land grabs of indigenous people's property occurring from colonial to neocolonial times. [Boryczka 2017:37]

Boryczka's framing is relevant for the case studies at hand because it draws our attention to why indigenous women's strategies and symbols deliberately overlap gendered and environmental concerns. Andrea Smith calls for academics to consider the racialized and environmental aspects of gendered oppressions affecting Native women, in order to reveal the structural and neocolonial aspects of present-day patriarchal governments. Smith writes,

An examination of how sexual violence serves the goals of colonialism forces us to reconsider how we define sexual violence (...) as not simply a tool of patriarchal control, but (...) a tool of racism and colonialism (...) Putting Native women at center of analysis compels us to look at the role of the state in perpetrating both race-based and gender-based violence. [Smith 2005:2]

As indigenous citizens increasingly communicate their resistance through social media, we respond to Smith's call to consider Native women's experiences in order to better understand the actions of the State. Media anthropologists have extensively documented the struggles of indigenous communities to overturn the power 
imbalance reflected in state and mass media representations of their activities (Ginsburg Abu-Lughod and Larkin 2002, Wilson and Stewart 2008). Indigenous media networks engage emerging digital social platforms in novel and strategic ways to reclaim their rights within social media public discourses (Alia 2010). David Gaertner (2016) articulates these tactical distance communications as a form of "landless territory" defense.

\section{THE PUSSYHAT AND TERRITORIES OF CONTESTED WOMANHOOD IN THE UNITED STATES}

There has been much to march for and against in the United States since 2016. The 45th president of the United States was inaugurated amidst one of the most contentious election seasons in recent history, one rife with 'pussy' references, and 'punctuated by penises' (Burleigh 2016). As of the spring 2017, the Congressional GOP, under Trump, was working hard to repeal the Affordable Care Act; efforts to this end continued through the fall 2017. Affordable Care Act repeal efforts threatened to make pregnancy a pre-existing condition and to remove other protections, including coverage for domestic violence screening. American senators Elizabeth Warren and Kamala Harris made headlines just months apart when both women were publicly hushed by male colleaguesand persisted, unsilenced. In September 2017, US Secretary of Education, Betsy DeVos, placed Title IX ${ }^{1}$ guidance for campus sexual assault under review, and in September 2018, the legitimacy of the Supreme Court was called into question by Brett Kavanaugh's problematic testimony regarding allegations of his committing sexual assault. Over the course of the last year in the United States, women have been openly defined by those in power as shushable, grabbable, expendable and conditionally pre-existent. 'Vaginas Make America', 'Pussy Power', 'Shed Walls: Don't Build Them', and 'Balls are Weak. Grow a Vagina' were but a few of the signs on parade among the thousands of folks in Washington, D.C. who participated in the \#WomensMarch in the wake of the inauguration of Donald Trump. Twitter, Instagram, and Facebook were filled with images from the protest. While it is true that gender discrimination is not new, it is equally true that our present moment is one in which women feel compelled to wear pussies on their heads, in the form of a pussyhat, as a visible and unmistakable reminder that it is not acceptable to make women's oppression a policy recommendation.

The pussyhat was conceived of by Jayna Zweiman (a Jewish artist) and Krista Suh (a Korean- and ChineseAmerican screenwriter) in 2016 as a visual symbol of protest against Candidate Trump's 'grab 'em by the pussy' remarks through a visual reclamation of the word and image. As someone recovering from a serious physical injury, Zweiman also wanted to create a project that participants, regardless of their ability to attend a March or if facing certain physical limitations themselves, could carry out, too. The pussyhat garnered quick and sizeable popularity with hats produced, swapped, and worn by the tens of thousands.

The pussyhat was not the only symbol of resistance during the Women's March 2017. On the streets of Washington, D.C. that day, Native North American women sang, danced, and wore special garments designed to draw attention to the challenges specifically facing Native women in the United States. For the Women's March, the Indigenous Women Rise group commissioned Designer Bethany Yellowtail (Northern Cheyenne and Crow) to design a scarf (Fairbanks 2017), which she crafted in a beautiful shade of turquoise and featured a women's warbonnet dance. The warbonnet dance ceremony, explains Yellowtail on her website, is the only sacred occasion during which women can don the warbonnet. Others invoked \#NoDAPL, a hashtag movement protesting construction of the Dakota Access Pipeline through tribal water sources. In doing so, these Native American women made an explicit connection between the pollution of their bodies and the pollution of their lands. To grab one, was to grab the other. To reclaim one, was to reclaim the other. And, in order to reclaim both, they might need to be 'grabbed back.'

The pussyhat is often interpreted to be a wearable way of women's 'grabbing back' control over women's bodies. To explore what reclaiming meant for wearers, just before the one-year anniversary of the Women's March, Shenton sent out an online survey via social media to ask anyone who was willing to provide their thoughts about the pussyhat. In addition, she emailed seven organizations dedicated to issues related to gender and social justice, including organizations dedicated specifically to Muslim women, transwomen, Native American women, and Black women, and asked them to share it with their constituents. Out of 78 survey respondents, about $85 \%$ identified as cisgender women ('cisgender' refers to the alignment of someone's gender identity with sex assigned at birth). Just over $75 \%$ identified as straight while the rest identified as asexual, bisexual, gay, lesbian or queer. Just over $90 \%$ identified as white, and $64 \%$ were under the age of 50 . About $78 \%$ currently reside in Southern states. Most did not wear the hat, regardless of gender identity, sexual identity, ethno-racial identity, age, or location; social identity was not a reliable predictor of whether someone did or did not wear the hat. This may come as a surprise to many given the prominent, near contentious, place the pussyhat enjoyed in coverage of the Women's March.

${ }^{1}$ A US federal law that prohibits sex discrimination educational programs receiving federal funds.

(C) 2019 by Author/s 
One question asked respondents to provide three words they most associate with the hat. Coding revealed that, by far, the most common descriptor for the pussyhat was something to do with power, empowerment, strength, or rising up. But opinions on this matter were not uniform. Some respondents observed the impossibility, in their view, of a hat that references genitalia, particularly one called the 'pussyhat,' as an effective tool to dismantle the broader societal tendency to equate women with their genitalia or to define them in terms of their reproductive roles. One 31-year-old cisgender, straight, white woman in Massachusetts said, 'The women's march was about more than just women and also tying women to their genitalia is not the best way to empower them.' A 44-yearold cisgender, straight, Latino man in Kentucky remarked that the hat does little to counteract how 'our culture (...) teach[es] people to see women as the sum total of the uses of a pussy.' A 39-year-old self-identified cisgender, straight, Native woman in Kentucky put it plainly, '...I wish it was something different that would have not been about vaginas.' Still, not everyone saw the reductionism of the hat as ignorance. Many saw it as purposeful, as did this 58-year-old cisgender, straight, white woman in Tennessee: 'Its [sic] like saying if you only respect me because I am a baby machine, then let's put it all out there for everyone to see.'

In addition to the hat's reductionism as limiting women's empowerment, objectification and frivolity were common critiques of the hat's messaging. One 30-year-old cisgender, straight, white man in Kentucky, for example, 'appreciated it's [sic] identity as a symbol of female power within a society that often seems afraid of that power, but (...) wondered if it trivialized the importance of the statement.' A 44-year-old cisgender, straight, Latino man in Kentucky put it more plainly,

Women complain a lot that they are objectified. (...) [1]t may have turned off women that might have participated. In a way I found it limiting. Not in a shameful way at all, but some women do object to pet names for their vagina. Both conservative and liberal.

While both of these critical respondents were men, women, too, expressed concern about the hat's frivolity: 'I thought they [the hats] were a little silly and I didn't want to be so closely associated with the word pussy' (cisgender, straight, white woman in Washington, D.C., 31). Lastly, one respondent was angered by the mere necessity of having to locate a symbol to protest a president who clearly does not value women and instead perceives them as objects: 'I felt angry that thousands of women had to put a symbolic vagina on their head to protest someone who was suppose [sic] to represent us. All of us' (cisgender, bisexual, white woman in OR, 42). Finally, and most importantly for this case study, reclamation or 'grabbing back' was also the second most popular reason given by self-identified cis white women for wearing the hat:

I think it is a perfectly acceptable symbol for the march. It is meaningful and cheeky, with a feminist message. It also empowers women by 'taking back' the pussy that have been grabbing (cis, straight, white woman in KY, 34).

One 43-year-old cisgender, straight, white women in Tennessee felt similarly: "At first it made me uneasy the double entendre with pussy, but the more I thought about it I thought it was empowering." She went on later,

At first I wasn't supportive. I had an instinctive reaction of revulsion to the word 'pussy' but using it helped me reclaim control of the word. I imagine it's a lot like how some people respond to the word 'moist.' It's not a word that bothers me but drives other people I know nuts.

However, a 51-year-old cisgender, straight, white woman in Massachusetts has little time for anyone who would criticize the pussyhat for 'vulgarity':

I find sexual abuse and sexual assault much more unacceptable than the use of the word 'pussy.' I wanted to reclaim my power and disempower any man or woman for that matter who chose to use that particular word in a derogatory sense to do harm to another female.

The project of reclaiming 'the feminine' has been a longstanding one for feminists, one that has involved 'grabbing back' what was taken by those in power; sometimes this reappropriation must embrace the damaging or simplistic portrayals of the feminine in order to destigmatize it.

Yet, feminists have been critical of a focus on biology as risking a too close association of women with nature (Ortner 1974) or fueling the social construction of women as determined by or beholden to the 'weaknesses' of their bodies. Still, a strategy of some feminists, including those within the ecofeminist movement, was to redefine the materiality of womanhood in productive terms so as to not give 'the patriarchy' the power to control interpretations of women's bodies and by extension, possibly, women's bodies themselves: 
(...) early radical feminism's close attention to the material, physical dimensions of power exercised through the female body (...) involved efforts to retrieve the vagina from patriarchy's definitional grasp. [Boryczka 2017:37]

This 'retrieval of the [colonized] vagina from patriarchy's definition grasp' is relevant to the experience of many of the survey respondents. Reclamation of the 'pussy' leaves unexplored other 'colonizations' faced by women whose voices were not widespread among survey respondents: Native women.

\section{Native North American Women, Bodies, and Land}

To be sure, Native American women faced specific suffering that was not encapsulated by the pussyhat. Their trauma includes the sterilization of thousands of Native women - at least 25 percent of Native women between the ages of 15 and 44 - during the 1970s (Lawrence 2000:400). Their trauma includes the targeting of Native women for reproductive surveillance through family planning initiatives by Indian Health Services in order to reduce the Native birth rate:

The average for white women was 2.42 children in 1970 and that number lowered to 2.14 in 1980; a difference of .28 children in the ten-year span compared to 1.99 for the Native American community. [Lawrence 2000:402]

Their trauma includes the exceedingly high rates of sexual violence endured by Native women as a form of 'conquest' past and present. Increasingly, their trauma includes the ongoing environmental racism that renders Native lands toxic as a consequence of fracking, oil pipelines, waste, and abandoned mines (Hult 2017; Lewis, et al. 2017), all of which harm maternal and infant health (Lewis, et al. 2017). Questions of sexual violence and reproductive injustice demonstrate just how interlocking body grabs and land grabs are, as Boryczka (2017) might say.

Disputes over oil pipelines cutting through Native American land-threatening the integrity of tribal burial grounds as well as posing hazards to the water supply-have drawn international attention; and 'virtually all uranium production takes place on or near Indian land' (Smith 2005:58). Ani Begay (Navajo) expressed statesanctioned environmental racism against Native communities in this way:

They [Trump and Pruitt] have no regard for sanctity of the land. It is only about dollar bills to them. I marched for our Mother Earth, for Native treaties and sovereignty and rights. I Marched for my children and for seven generations out. [Farris 2017]

Beyond environmental racism, for Native women, bodily and territorial sovereignty overlap in other ways:

' $[\mathrm{N}]$ on-Indians (...) reportedly commit the vast majority (96\%) of sexual violence against Native women. (...) [N] on-Indians now comprise $76 \%$ of the population on tribal lands and $68 \%$ of the population in Alaska Native villages' (Indian Law Resource Center).

Sarah Deer (Muscogee [Creek]), scholar of tribal and federal laws as they relate to rape and other forms of violence perpetrated against Native women, reveals the stark reality of the vastly underrecognized topic of sexual assault against Native women who experience some of the highest rates of rape in the country (Deer 2015). High rates of sexual violence on tribal lands in conjunction with dismal track records of governmental prioritization often spell catastrophe for Native American women in the aftermath of assault (Asetoyer, et al. 2015). These women often seek medical attention in Indian Health Services clinics, and many of these clinics have a history of suboptimal care ranging from long waits to denial of services like emergency contraception (Asetoyer 2015; Asetoyer, et al. 2015). In other words, reproductive justice groups often focus on choice, but not all choices take place under similar circumstances (see Smith 2005:99-100).

From the words of Shenton's survey respondents, it is clear that the pussyhat did not fit every marcher's goals, experiences, or grievances. Sydne Rain (Muscogee [Creek]), co-founder of University of Oklahoma's Indigenize OU, commented on her Twitter feed various moments when she felt excluded, ignored, offended, and discriminated against. Journalist Tatiana Tenreyro (2017) was able to capture Sydne Rain's discontent with her experiences that day with screenshots of Rain's tweets in real-time. Here are a few striking examples:

hokte@sydnerain: Ashley and I started a chant, 'You're on stolen land.' WW shot us ugly looks. One shouted in her face, 'We know but it isn't our fault!'

hokte@sydnerain: I always try to think about my connection to the land. Think about whose ancestors I'm standing on. And these WW ask me if I am a real human. 
hokte@sydnerain: We were visible. They took pictures then refused to take our fliers on pipelines, fracking, and \#MMIW in Oklahumma.

Here we see the importance for Rain of her connection to the land and her frustration that more of the marchers did not see it as worth marching for; here we see references to Native land stolen hundreds of years ago by white colonizers and for generations thereafter; here were see the continued delegitimation of Native American ancestry along with neo-colonial threats of fracking and pipelines. Hashtag feminism serves as a means to publicly reclaim women's bodies and lands via social media when the broader society needs to be reminded of the many, multisited territories of contested womanhood.

\section{THE PACHAMAMA AND TERRITORIES OF CONTESTED WOMANHOOD IN THE ANDES}

From Standing Rock, North Dakota, to the Andean altiplano, fracking and mega-mining projects increasingly threaten indigenous territories. While they constitute only $6 \%$ of the global population, indigenous people represent nearly one-third of the rural and extremely poor, and these rural communities are facing accelerating rates of land dispossession associated with mining and resource extraction. Across the Andes, and increasingly in the United States, local leaders are risking incarceration with the increased criminalization of protest (UN 2010). Indigenous activists are overwhelming turning to global communications systems to direct international media attention toward their plight.

The Andean women in this case study who invoke the Pachamama against mountaintop removal and groundwater contamination are claiming an essential connection to the landscape that emphasizes their relation to nature (Haraway 1991), and biological role as mothers (Ortner 1972). Generations of scholars have debated whether women's association as 'closer to nature' hinders or helps women's empowerment ${ }^{2}$ (Shiva 1989, Hiltebeitel \& Erndl 2000, Orozco Mendoza 2016). This case considers Aymara women's self-portrayal on social media as inherent defenders of nature, analyzing their political identification with Pachamama within \#NiUnaMenos demonstrations in highland Peru.

In recent years, Andean state leaders, including Bolivian President Evo Morales and former Ecuadorian President Rafael Correa, publicly declared their respect for Pachamama within the context of announcing extensive extraction projects so that the mother earth could 'provide for her people.' This Pachamamismo is a rhetorical platform that pulls Andean cosmology into policy discourse, emphasizing a moral obligation to defend and protect the Pachamama that is ironic compared to state practice. Indeed, despite this moral ethos, extraction is moving to a more destructive model that violates clearly stated ethical responsibilities toward Pachamama while wreaking havoc on public health (Li 2015). Against pro-mining rhetoric, many Aymara reclaim Pachamama as a political rallying cry; one recent Facebook post circulated among UMA activists was a blazing green sign that read: 'Pachamama, Si! Pachamamismo, No!'- in other words, 'Mother Earth, Yes! Poorly-disguised Extraction, No!'

On August 13, 2016, hundreds of thousands of women gathered in Lima and in cities across Peru to protest femicide and intimate partner violence, in the largest march in the nation's history. ${ }^{3}$ The multi-sited march against gendered abuse involved a panoply of symbolic representations: urban women strode through cosmopolitan Lima in cut-offs with blood red paint dripping down their thighs, in a visceral reference to forced sterilizations. In the largely white colonial city of Arequipa, men supported the movement carrying signs that read: 'careful, machismo kills'. In the indigenous Puno region of Peru, Aymara women marched with banners that operationalized their relationship to Pachamama, an Andean deity, emphasizing an explicit connection between bodily sovereignty and land sovereignty [Figure 1]. 'No More Silence!' 'Not One More Death!' and 'My Body, My Territory!' were the key phrases shouted by thousands of Peruvian women as they marched through the streets of cities across Peru. Baring images of a bloody hand with a heart etched in the center, some with bright red paint like blood dripping down their thighs, protesters pushed banners that said, 'Ni Una Menos', Not One Less, declaring that "To touch one of us is to touch all of us." Images of women's bodies lacerated by intimate partner violence were deployed across the country in a multi-city march on August 13, 2016. The \#NiUnaMenos hashtag movement, which had begun in Argentina the year before, sparked in Peru in reaction to multiple high-profile incidents of intimate partner violence. Peruvians had just endured a presidential election wherein one candidate, the daughter of former

\footnotetext{
${ }^{2}$ Ecofeminism is a theoretical framework which traces the subordination of women and the environment through patriarchal development, analyzing how women are simultaneously subject to multiple forms of domination through the parallel control of land and women's bodies. Ecofeminism, however, leans into the idea that women are closer to "nature", and has been widely critiqued for its essentialism - the claim that groups have an inherent set of characteristics that make them who they are, as opposed to having culturally constructed identity.

${ }^{3}$ As reported by Peruvian news outlets, see for example La República (in Spanish), August 14, 2016, "La màs grande de la historia".
} 


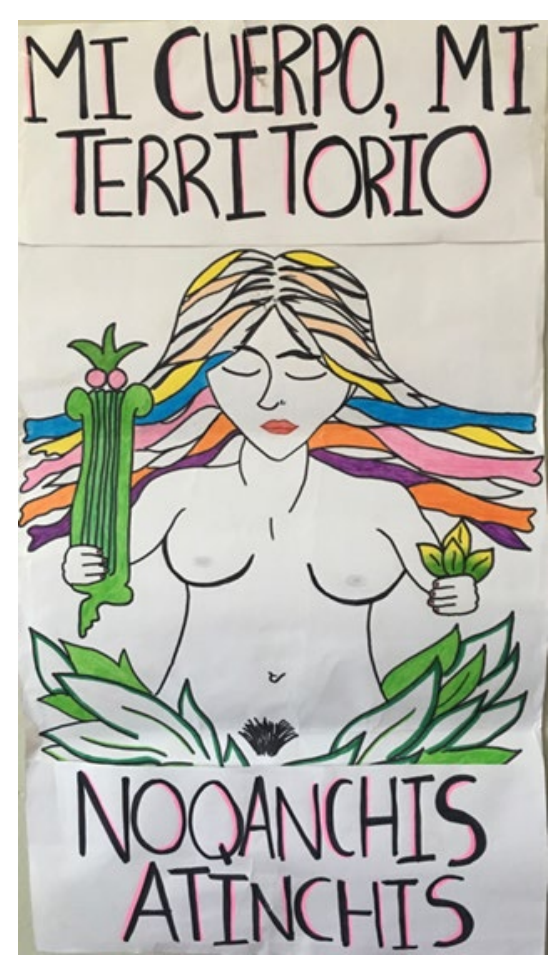

Figure 1. A banner emphasizing an explicit connection between bodily sovereignty and land sovereignty

president Alberto Fujimori, had ignited social memory of her father's era of forced sterilizations, which were largely perpetrated against indigenous communities. In a speech at Harvard University, Keiko Fujimori blamed the cruel surgeries on doctors, despite the fact that medical professionals had been compelled by the national health ministry quotas set by her father's administration. Nationwide, women took to the streets to protest against the visceral realities facing women in Peru.

2018 marks the 70-year anniversary of the Universal Declaration of Human Rights (UN General Assembly 1948), yet violence against women remains among the most egregious humanitarian issues worldwide. In Latin America, $40 \%$ of women experience physical violence over the course of their lives; in Peru, among rural and indigenous women of the Puno region, more than $75 \%$ suffer some form of violence (Human and Environmental Rights Puno 2017). The adverse impacts of increased mineral extraction in the region, and the corresponding loss of resources and rights to self-determination, appear to be compounding rates of interpersonal abuse in indigenous communities (Jenkins 2014). These industries are destroying the animate landscape that the Aymara consider to be sacred. They call her Pachamama, or Mother Earth. For rural indigenous women in this Andean context, the violent plunder of a goddess-imbued landscape intersects with women's experiences of violence at the hands of men, medics, and the state. Cases of violence against women increased by $18 \%$ from 2015; femicides increased by a third from 2015 (Human and Environmental Rights Puno 2017). In July of that same year, Alberto Fujimori and his ministers of health were exonerated of criminal responsibility for the wave of forced sterilizations in the 1990s that targeted poor, rural women. The ruling stated that 'the reproductive health and family planning program had not violated human rights as part of a state policy.' Over the course of the last two years in Peru, women have been openly defined by those in power as rapeable, sterilizable, sub-human beings. The \#NiUnaMenos movement, which has reemerged each year since its beginning - digitally incubating as a social media hashtag in between manifestations - evidences the need for renewed consideration of essentialism in studies of social protest.

Feminist analyses of the resistance efforts and tactics of those at intersecting power disadvantages have been instrumental to understanding social change. Cavagnaro examined Andean women's efforts to decolonize womanhood at scales ranging from the interpersonal (the body) to the ecopolitical (the landscape). Based on fieldwork conducted in 2016 and 2017 in the Puno region, Cavagnaro analyzes the \#NiUnaMenos march through on-site fieldwork involving participant observation, interviews, focus groups, as well as post-event social media analyses.

In 2016, while running for president, Peruvian candidate Keiko Fujimori refused to acknowledge her father's administration's responsibility for establishing coercive long-term birth control quotas in the 1990s, which targeted citizens in poor and rural regions for forced sterilization. The younger Fujimori insisted that administration of birth control had been in the hands of individual medics, thus obscuring the structural and racial dimensions of these programs. These quotas, in turn, were influenced by broader global financial regimes-including the World Bank, which, since the 1970s, as Eduardo Galeano writes, has been giving 'priority in its loans to countries that 
implement birth control plans' (Galeano 1979)—plans which are directed at racialized population control. Highland Andean bodies thus became sites for neocolonial Malthusian praxis, and the politics of birth control rhetoric took on vastly different implications for indigenous citizens than for their non-indigenous compatriots.

In Peru, the Fujimori administration's programs were advertised as a way of reducing poverty through population control. To appreciate why centering birth control as the unifying cause for a broad-based women's mobilization is problematic, it is important to understand the neocolonial eugenics of many state reproduction mandates affecting indigenous communities across the globe. Smith quotes Professor Inés Hernández-Avila (Nez Perce/Tejana), who notes,

it is because of a Native American woman's sex that she is hunted down and slaughtered, in fact, singled out, because she has the potential through childbirth to assure the continuance of the people. [Smith 2005:79]

Indigenous women in the Puno region of Peru are continuously at work to decolonize their bodies amid radical attempts at recolonization by political and corporate entities, who develop indigenous land without consent in the present (Jenkins 2014), and work to reduce indigenous populations without consent in the long-term.

In Peru, women in the \#NiUnaMenos March in Lima symbolically leveraged the bloodied uterus to react against the forced sterilization of women and the threat to their reproductive freedoms. But what this does symbolize to women in Peru who have been written out of heteronormative women's rights conversations by virtue of their sexual identities? In the Peruvian Andes, Aymara and Quechua women in the \#NiUnaMenos March invoked the Earth Mother, Pachamama, operationalizing the trope that 'women are to nature as men are to culture' (Ortner 1972), where 'nature' is the fecund body or landscape under attack, and 'culture' is the Western medic performing surgery, or the mining corporation. Thus, as Andean women continue to face threats to their bodies on a broad scale, one feminist concern is that their strategies deploy reductive gender stereotypes that may further marginalize the most vulnerable: women who love other women in rural indigenous communities, and are socially targeted or shunned for violating the 'gender complementarity' of Andean Cosmopolitics (De La Cadena 2015). So, what do we do when the symbols that make the strongest statement are at the same time reductionist, conforming to, and perhaps even serving to reinforce, the damaging gender stereotypes that define women by their genitalia, the relationality of that genitalia to a male "counterpart," and the social reproduction their genitalia promise?

\section{Aymara and Quechua Women, Bodies, and Land}

Study participants in the Puno region, Aymara and Quechua of the Andean highlands, ranged in age from 21 to 67. Cavagnaro interviewed 12 activists associated with the organization UMA del Abya Yala, the Union of Aymara Women Spokespeople (UMA), about their participation in the march. UMA hosts a feminist talk radio station in the Puno Region, which airs internationally across Lake Titicaca, reaching the Bolivian shores and connecting highland Aymara and Quechua women of both nations. In addition to their radio programming, UMA functions as a women's rights organization, holding gender rights workshops in Aymara communities south of Puno.

During the 2016 March, UMA activists struggled against neo-colonizing mass media narratives aimed to 'gaslight' indigenous social memory. As one Aymara respondent recounted:

I had always heard that there were so many cases of forced sterilization, but since I didn't know anyone this had happened to (...) I thought, it seemed far away. I was wrong. The idea, the cultural idea here, was that the women that this had happened to, they must have been 'easy' women. This is what so many of the women victims [later] told (...) that they had been treated in this way by their families. So, they decided to shut up and to abandon the [legal] process (...) But on the news they are not talking about this very much and so the youth doesn't know very much about it, and it seems like it doesn't interest us, because we didn't live it.

The Aymara and Quechua the altiplano, or Andean high plains, inhabit landscapes which are redundantly claimed, occupied, and brutalized by mining companies, development firms and mountaintop removal, leaving them scarred with open-pit mines and poisoned with cyanide. The adult Quechua and Aymara women who live within these landscapes suffered the worst extents of oppressive state health programs. Through enactment of Fujimori-era eugenics policy, these women's reproductive rights were claimed, their bodies colonized, and their uteruses brutalized by coercive state health ministries tasked with of numbers of sterilizations to perform, leaving them barren, socially marked, physically scarred and psychologically afflicted. These women are engaged in an ongoing battle to decolonize self and community. And yet, a further daunting challenge afflicts their resistance efforts: the 
need to first decolonize the broad propagandist narratives that claim to work towards population control in the hopes of reducing 'rural poverty'.

This strawman population argument has served to disunite generations of indigenous women. Intracommunity women's radio programming and gender rights training workshops are helping to counteract these patriarchal narratives. A young Aymara woman from a rural community who went to school in Puno recalled:

Before I went and I listened at the reunions, I was convinced that the sterilizations were a good thing. Because, I thought, there are so many children. And the parents don't have the economic means to care for them. I thought that it would be good for the birth rates in Peru. When I went to the meetings, I was so surprised that it was such a negative process for the men as well as the women. (...) Later, we learned that those medical professionals who performed more sterilizations actually earned more money.

Rural women's language barriers, educational differentials and economic limitations made these highlanders soft targets for state workers who were threatened with unemployment if they did not fill their quotas. However, their intersectional experience of violence as rural Aymara women means that state campaigns aimed at reducing indigenous populations not only colonize women's bodies to facilitate the future colonization of their territories, they also exacerbate women's experience of violence within their communities by triggering cultural conflict rooted in Aymara notions of womanhood and manhood. Another young UMA activist recalled:

ONAMIAP [The National Organization of Andean and Amazonian Indigenous Women of Peru], they held meetings for survivors of this, and we heard about it from men and women who went through it. One man -- he was talking about what they did to him, the vasectomy -- and he said that he is now 'not like a man' (...) He said this, and said others talk this way about [the procedure] (...) that it stops what makes you a man. And now he can't work. He is dark (...) and the women, too, now they can't work, they feel so heavy and burdened all the time, depressed.

Centuries of racism and neocolonial governance disempowered indigenous Andeans' sense of resistance against the medical staff, who the intimidated rural men and women recognized as 'educated', mestizo agents of the state. A young Quechua man, the only current male member of UMA, in whose community dozens of women were targeted, reflects with a hoarse whisper:

There were so many Quechua women from this area that had this happen to them and didn't even know it was happening, and also to the Aymara in Puno region but more so to the Quechua. They would go to the Health Centers for some reason, for some malady, and the nurses would ask them things like, "You, how many children do you have?" And they would answer, 'Oh, I have five', or 'I have three', or 'I have four' (...) and the nurses would say, "Oh, but this is so many, it is for this reason that you are feeling like this, that you are sick this way. You should not have any more children." And the women would stay quiet. They would not speak back to the medical professional. They were timid, and then the doctor or the nurse would say, "Here, come on up on the table, we will examine you, to see what is wrong," and so on. And it was there that they would put things in them, or sterilize them; there were different methods: a cobre [copper-T IUD], or ligadora [colloquial reference to tubal ligation] (...) They did these things to men, too, the vasectomies. They didn't tell them why.

In post-march interviews, many Aymara and Quechua women in the highlands reported their motivations for participating as a simultaneous resistance against the patriarchal colonization of their beings and the neocolonial destruction of their landscapes by mega-mining projects. Likening her body to the body of Pachamama, and her roles as mother, nurturer and tender of the soil to Pachamama's function as material provider for the people, one Aymara leader reflected:

It is us, as women, who are closer to her, who understand what is happening to her. We lead in defending the Pachamama because she suffers as we do.

Western academics call this strategically associative closeness of 'woman' to 'nature' ecofeminism. In its analysis of parallels between the patriarchal treatment of women and the consumerist development of landscapes, ecofeminism is inherently gender essentialist, rooting 'womanhood' in the physicality of the body and what the body can produce. The downside to ecofeminist discourse is its biological determinism, and in particular for Andeans, the cis-gendered, heteronormativity of the 'gender complementarity', as described by chachawarmi, the Andean gender concept informing invocations of Pachamama. Across cultural frameworks and national borders, for decades, women have been discussed as more environmentalist and 'closer to nature' (Shiva 1989, Haraway 1991, Gaard 2015). 
Regardless of veracity, Western ideologies associating both women and the indigenous as closer to 'nature' are engaged by indigenous movements seeking autonomy and resources, both at local and international scales. The importance of such rhetoric cannot be overstated; Andrew Canessa (2012:2-4) notes the distinct global currency of indigeneity with the UN and other major funding bodies. Andean state leaders now grant citizenship rights to Pachamama in Ecuador and in Bolivia, while engaging tropes of sacred feminine landscapes (Cochrane 2014) and appealing to UN funding foci on climate change and women, despite their extraction-dependent economies and continuous, broad-scale open-pit mining.

Andean women's relationality to Pachamama, on the other hand, serves to bring indigenous women and their allies together and provide an organizing principle rooted in Andean cosmology that helps to rhetorically shape and promote their defense of the landscape. An expanding feminist talk radio network in the region supports this effort. Referring to her radio activism on Radio Pachamama, in Puno, one UMA activist noted:

Everybody listens to our participation and our words. Our sons and daughters also listen.

We tell them about the situation of Mother Earth.

As communities of Aymara women came together for the march, they shared experiences across generations that decolonized the younger women's understanding of the state's claim that Fujimori-era sterilizations were geared towards a pro-environmental, anti-poverty program, helping the younger generation toward the realization that these policies were neocolonial acts of gender violence propagated by the state. Identification with the Pachamama revalorizes women's roles in Andean society—though in doing so, thus far fails to deconstruct the reductive gender norms that contribute the erasure of women who love women in these communities. When asked about Aymara women who love other women, one respondent illustrated:

Aymara culture is still so repressed about sexuality. If women love women, they hide it -- they have children anyway, or they move to Lima (...) It brings shame on their family; sometimes the family is accused of wrongdoings or evil.

To wrest their rights to self-definition back from mass media stereotypes that portray sterilized women as having been sexually overactive over-populators, Andean activists' leveraging of essentialized symbolic connections serves to lay claim to women's forms of power and authority, toward the defense of their bodies and territories. Once brought together by these shared symbolic affinities, these women shared testimonies that helped to decolonize their understandings of social memory, which had been polluted by state propaganda. Hitherto, in the altiplano, this tactic has broken down for women who love women, as there is no, pre-state Aymara concept for same sex rights. But is this changing in the era of hashtag feminism, as women's cultures, symbols and political agendas converge in this new realm of digital grievance. When Pachamama goes global, leveraged by Andean activists on the radio, social media, and in the streets blockading, perhaps she does so as a single woman, leaving behind her implicit male counterpart who is rooted in the intimate binaries implicit in chachawarmi, or gender complementarity. However, in the everyday lived experiences of women in the Andes, heteronormative gender ideals erase the experience of same-sex love in rural indigenous communities, where individuals who stray from the heterosexual binary expected by community social norms are punished through ostracism and physical and verbal abuse that often extends to their families.

\section{\#TheFutureIsFemale? HASHTAG FEMINISM AS COMPLAINT DISCOURSE}

Cavagnaro is appropriately haunted by a reading she once did for a gender theory class, during a lesson on expressions of the subaltern voice; she'll do her best to frame it here: There was a group of houses close together in a community, and it came to be that a young woman was being brutally beaten by her spouse. At night, others in the surrounding homes heard her sounds of pain but the social contract left her silent, and legal recourse, impossible. Unable to physically stop the abuse, the women of the community finally took up their drums and surrounded the house of the abuser. They drummed and they drummed, the constant, increasing rhythm growing louder as more and more women from the community left their homes to join in.

This is the power of complaint discourse ${ }^{4}$, with social media emerging as a beating drum. In the 21 st century, what imbues complaint discourse with such notable potential is the ability of social media platforms to scale up the level of conversation and instantaneously connect those who share a cause with those who might influence policy and public opinion. This is what happened when activist Ana Maria Archila and college graduate Maria

\footnotetext{
${ }^{4}$ For community studies of complaint discourse in anthropology, see Lorna Marshall, 1976 and 1999; Richard B. Lee, 2003;
} Harriet Rosenberg, 1993. 
Gallagher accosted Republican Senator Jeff Flake during the Kavanaugh hearings, beseeching him to recognize that a vote in favor of the embroiled nominee was a vote telling women they do not matter.

Among the Aymara, women's grassroots political activism increasingly reaches a pan-indigenous and international audience of sympathizers. They tweet and retweet, their consistent, quasi-repetitive messaging reaching broader and broader media sources until, as was the case during the 2011 El Aymarazo uprising in Puno district, they're the subjects of punditry on $\mathrm{Al}$ Jazeera, $\mathrm{CNN}$ and Fox News. Their multimedia ecofeminism, in addressing relationships between capitalist domination of nature and men's domination of women, has been a useful communication strategy for Aymara women leveraging the Pachamama to simultaneously address multiple forms of male domination in their communities. At present, a grassroots media commentary by Andean women circulates on Facebook, captioned 'Pachamama Si, Pachamamismo No!' evidencing women's dissent against the neoextractive policies of plurinational Ecuador and Bolivia. In the Amazon, the Women against TIPNIS are protesting the construction of a superhighway through vast expanses of rainforest. Global media strategies meet localized media ecologies to combat the 'menace of multiculturalism' (Hale 2002), as grassroots movements lean into their place-basedness to establish visibility and presence schemas focused heavily on globalized complaint discourse and localized actions (Jeffries 2010). Meanwhile, this scaling-up of protest is increasingly necessary as a surge of farright state regimes rolls back on gender rights and territory agreements across the Americas.

We would be remiss not to observe that the gender essentialism of women's hashtag feminism in the case studies presented has been in active response to a gendered pattern of affronts. As myriad, macho politicians speak to mainstream media in misogynistic ways, all the while holding the keys to the highest levels of power and government, women take to social media to engage in one of the most tried and tested forms of subaltern resistance: complaint discourse.

In the United States, a focus on the experiences of Native women in demonstrations on Washington shows that often, pro-woman discourses obscure the history of erasure that has affected Native women's access to a variety of societal resources; this includes pro-choice platforms' lack of concern for the specifics of indigenous women's reproductive rights and a failure to be attentive to how this involves their homes and lands. The echoes of a national disruption caused by the US Women's March can be seen in the ongoing wave of sex-abuse revelations and inquiries now directed at some of the highest-level public faces in the country.

Hashtag-incubated via social media between public manifestations, the \#NiUnaMenos movement continues and has held a march in Peru each year since 2016. On June 2, 2018, protesters lined the streets outside the Palace of Justice in Lima with signs that read 'No more immunity, the murder must pay!' in reference to Peruvian President Martin Vizcarra's comments about a woman recently burned to death by her stalker on a public bus: 'Sometimes that's how life is and we have to accept it. ${ }^{5}$ Meanwhile, in the United States, Trump nominee Brett Kavanaugh ascended to the Supreme Court after dodging Senate Judiciary questions regarding multiple, detailed accounts of sexual assault from women in his former communities, the most prominent of whom has testified before the US Senate and submitted to polygraph testing, which she passed. Women have taken to social media with the hashtags \#BelieveWomen and \#StopKavanaugh to protest the senate majority's attempts to proceed with Kavanaugh's nomination. This highly publicized resistance served to compound gender divides between American voters, as Marist polls suggest that Kavanaugh's hearings, and the gendered reaction thereto, galvanized conservative males to vote in the November 2018 elections. ${ }^{6}$

Meanwhile, in Brazil, hundreds of thousands took to the streets of multiple cities nationwide to protest farright presidential candidate Jair Bolsonaro, under the hashtag movement \#EleNão, 'Not Him'. Bolsonaro's misogyny has been widely publicized: in 2014 he told a Brazilian congresswoman that he wouldn't specifically rape her because she didn't 'deserve it', and in 2017 was quoted as suggesting that a man's siring of a daughter demonstrated 'weakness.' Anti-Bolsonaro supporters of the \#EleNão movement, as covered by global media outlets, are already expressing biologically deterministic ideals about women and gender, even as they attempt to support women's rights. A female university professor from Rio told Al Jazeera,

Bolsonaro is the expression of masculinity, and cannot handle the feminine, which is the most beautiful aspect of women... Women, in contrast to men, aren't born with the illusion that we have a gun between our legs. [Child and Soares 2018]

As the unfortunate surge of far-right, gender oppressing state leadership continues, social scientists who analyze culture change should pay careful attention to how marginalized groups are using media to bypass increasingly misogynistic institutions, and consider the multiple fronts of conflict expressed in their protest symbolism.

\footnotetext{
${ }^{5}$ See Dan Collyns' article in The Guardian, "Fury over Peru president's reaction to woman's murder by stalker", June 5, 2018.
}

${ }^{6}$ September 2018 Marist poll, National Public Radio, All Things Considered October 3, 2018.

7 Al Jazeera, "Brazil: Thousands of women rally against Bolsonaro", September 29, 2018.

(C) 2019 by Author/s 
Somewhere there needs to emerge a focus on (alter)Native views that centers the experiences of 'non-normative' womanhood, following women who lead in warbonnet scarves or bowler hats, as they defend womanhood in some cases, deconstruct it in others, and continue to decolonize their bodies and their lands. From the collective beating of drums to the rapid-fire retweets of \#TimesUp, these battle-forged tactics surface in times of increased, hegemonic gender conflict.

\section{ACKNOWLEDGEMENTS}

Kellie Cavagnaro: My profound appreciation extends first to my co-author, Jamie Shenton, whose wisdom and support have impressed upon me the immeasurable value of feminist collaboration. I would like to thank our reviewers for their formative commentary and our editor, Simon Stewart, whose kind communications advanced this work. For Rosa, Yeny, Irma, and the women of the Union of Aymara Women Spokespeople of Abya Yala, I have the utmost respect; it continues to be my honor to learn from you. Thanks to my anthropology doctoral advisor, Carwil Bjork-James, and to my CMAP cohort at Vanderbilt for their feedback. Early phases of my fieldwork were generously funded by the Social Science Research Council, to whom I am most grateful.

Jamie E. Shenton: I would like to thank, first and foremost, my co-author Kellie Cavagnaro. Together we cultivated motivation and inspiration for one another. I would also like to express my deep gratitude to Jessa DeLuca, a student researcher who spent endless hours with me in the summer discussing political symbolism, feminist theory, and what to make of the pussyhat. I am grateful to the editor, Simon Stewart, and the anonymous reviewers for their developmental comments. I would like to thank my family for their support during this process as well as my colleagues at Centre College. And, finally, I would like to recognize and appreciate the many, many contributors to this vibrant wave of hashtag feminism.

\section{REFERENCES}

Agarwal, B. (2000). Conceptualising Environmental Collective Action: Why Gender Matters. Cambridge Journal of Economics, 24, 283-310. https://doi.org/10.1093/cje/24.3.283

Alia, V. (2010). The New Media Nation: Indigenous Peoples and Global Communication. Oxford: Berghahn Books.

Arora-Jonsson, S. (2011). Virtue and Vulnerability: Discourses on Women, Gender and Climate Change. Global Environmental Change, 21(2), 744-751. https://doi.org/10.1016/j.gloenvcha.2011.01.005

Asetoyer, C. (2015). Native American Women Deserve the Same Reproductive Health Care as Any Other Woman, No Questions Asked. ACLU website, October 2015. Available at: https://www.aclu.org/blog/reproductivefreedom/birth-control/Native-american-women-deserve-same-reproductive-health-care (Accessed January 30, 2018)

Asetoyer, C., Kingfisher, P., Deer, S. and Amnesty International. (2015). Lack of Equal Access to Health Services for Native American and Alaskan Native Women Following Sexual Violence: Report to the UN Working Group on the Issue of Discrimination Against Women in Law and Policy. US Human Rights Network website, October 2015 (Accessed January 30, 2018)

Black, S. (2017). KNIT+RESIST: placing the Pussyhat Project in the context of craft activism. Gender, Place \& Culture: A Journal of Feminist Geography, 24(5), 696-710. https:/ / doi.org/10.1080/0966369X.2017.1335292

Bordo, S. (2004). Unbearable Weight: Feminism, Western Culture, and the Body. Berkeley and Los Angeles, CA: University of California Press.

Boryczka, J. (2017). An Anatomy of Sexism: The Colonized Vagina. New Political Science, 39(1), 36-57. https://doi.org/10.1080/07393148.2017.1278845

Burleigh, N. (November 14, 2016). The Presidential Election was a Referendum on Gender and Women Lost. Newsweek website. Available at: http:/ /www.newsweek.com/2016/11/18/hillary-clinton-presidential-electionvoter-gender-gap-520579.html (Accessed January 30, 2018)

Burman, A. (2011). Chachawarmi: Silence and Rival Voices on Decolonization and Gender Politics in Andean Bolivia. Journal of Latin American Studies, 43, 65-91. https://doi.org/10.1017/S0022216X10001793

Butler, J. (1990). Gender Trouble. New York: Routledge.

Canessa, A. (2012). Intimate Indigeneities: Race, Sex and History in the Small Spaces of Andean Life. Durham, NC: Duke University Press. https://doi.org/10.1215/9780822395379

Child, D. and Soares, J. P. (September 29, 2018) Brazil: Thousands of women rally against far-right Bolsonaro. Al Jazeera website. Available at: https://www.aljazeera.com/news/2018/09/brazil-thousands-women-rallybolsonaro-180929231001428.html (Accessed October 3, 2018)

Cixous, H. (1976). The Laugh of the Medusa. Signs, 1(4), 875-893. https://doi.org/10.1086/493306 
Cochrane, R. (2014). Climate Change, Buen Vivir, and the Dialectic of Enlightenment: Toward a Feminist Critical Philosophy of Climate Justice. Hypatia, 29(3), 576-598. https:/ / doi.org/10.1111/hypa.12099

Collins, P. H. (2000[1990]). Black Feminist Thought: Knowledge, Consciousness, and the Politics of Empowerment, $2^{\text {nd }}$ Edition. New York, NY: Routledge.

Crenshaw, K. (1989). Demarginalizing the Intersection of Race and Sex: A Black Feminist Critique of Antidiscrimination Doctrine, Feminist Theory and Antiracist Politics. University of Chicago Legal Forum, special issue: Feminism in the Law: Theory, Practice and Criticism. 139-168.

De la Cadena, M. (2015). Earth Beings: Ecologies of Practice across Andean Worlds. Durham, NC: Duke University Press. https://doi.org/10.1215/9780822375265

Deer, S. (2015). The Beginning and End of Rape: Confronting Sexual Violence in Native America. Minneapolis, MN: University of Minnesota Press. https://doi.org/10.5749/minnesota/9780816696314.001.0001

Dembour, M. (2001). Following the movement of a pendulum: between universalism and relativism. In Culture and Rights: Anthropological Perspectives, edited by J. K. Cowan, M. Dembour, and R. A. Wilson, 56-79. Cambridge, UK: Cambridge University Press. https://doi.org/10.1017/CBO9780511804687.005

Escobar, A. (2001). Culture sits in places: reflections on globalism and subaltern strategies of localization. Political Geography, 20(2), 139-174. https://doi.org/10.1016/S0962-6298(00)00064-0

Fairbanks, J. (January 2017). Indigenous Women Rise: Women's March on Washington. Native Americans in Philanthropy website. Available at: https://Nativephilanthropy.org/indigenous-women-rise-womens-marchwashington/ (Accessed January 30, 2018)

Farris, P. (March 2017). Indigenous Women Rising: Women's March on Washington," Cultural Survival Quarterly Magaqine website. Available at: https://www.culturalsurvival.org/publications/cultural-survivalquarterly/indigenous-women-rising-womens-march-washington (Accessed January 30, 2018)

Gaard, G. (2015). Ecofeminism and Climate Change. Women's Studies International Forum, 49, 20-33. https://doi.org/10.1016/j.wsif.2015.02.004

Gaertner, D. (2016). Indigenous New Media and Digital Storytelling. Novel Alliances: Allied Perspectives on Literature, Art, and New Media. Blogpost, October 30.

Galeano, E. (1979). Open Veins of Latin America: Five Centuries of the Pillage of a Continent. New York: Monthly Rev Press. https://doi.org/10.14452/MR-030-07-1978-11_2

Ginsburg, F., Abu-Lughod, L. and Larkin, B. (2002). Media Worlds: Antbropology on New Terrain. Berkeley: University of California Press.

Hale, C. R. (2002). Does Multiculturalism Menace? Governance, Cultural Rights and the Politics of Identity in Guatemala. Journal of Latin American Studies, 34, 485-524. https:/ / doi.org/10.1017/S0022216X02006521

Haraway, D. (1991). Simians, Cyborgs and Women: The Reinvention of Nature. New York: Routledge.

Hiltebeitel, A. and Erndl, K. eds. (2000). Is the Goddess a Feminist? New York: New York University Press.

Hult, J. (March 2017). Women of Standing Rock Aren't Backing Down. USA Today website. Available at: https://www.usatoday.com/story/news/nation/2017/03/11/women-standing-rock-arent-backing-down/ 98975956/

Human and Environmental Rights Puno. Annual Report. Puno, Peru 2017. Print.

Indian Law Resource Center (ILRC). Ending Violence Against Native Women. Indian Law Resource Center website. Available at: http://indianlaw.org/issue/ ending-violence-against-Native-women (Accessed March 23, 2019)

Jeffries, F. (2010). Asking We Walk: The Zapatista Revolution of Speaking and Listening. In Kevin Howley, ed. Understanding Community Media. Thousand Oaks: Sage Press.

Jenkins, K. (2014). Women, Mining and Development: An Emerging Research Agenda. The Extractive Industries and Society, 1, 329-339. https://doi.org/10.1016/j.exis.2014.08.004

Lawrence, J. (2000). The Indian Health Service and the Sterilization of Native American Women. American Indian Quarterly, 24, 400-419. https:// doi.org/10.1353/aiq.2000.0008

Lewis, J., Hoover, J. and MacKenzie, D. (2017). Mining and Environmental Health Disparities in Native American Communities. Current Environmental Health Reports, 4(2), 130-141. https://doi.org/10.1007/s40572-017-0140-5

Li, F. (2015). Unearthing Conflict: Corporate Mining, Activism \& Expertise in Peru. Durham: Duke University Press. https://doi.org/10.1215/9780822375869

Meinzen-Dick, R., Kovarik, C. and Quisumbing, A. (2014). Gender and Sustainability. Annual Review of Environment and Resources, 39, 29-55. https:// doi.org/10.1146/annurev-environ-101813-013240

Merchant, C. (1980). The Death of Nature: Women, Ecology and the Scientific Revolution. New York: Harper and Row.

Millet, K. (1970). Sexual Politics. London: Rupert Hart-Davis, Ltd.

Orozco Mendoza, E. F. (2016). Maternal Activism. The Wiley Blackwell Encyclopedia of Gender and Sexuality Studies. https://doi.org/10.1002/9781118663219.wbegss725 
Ortner, S. (1972). Is Female to Male as Nature is to Culture? Feminist Studies, 1(2), 5-31. https://doi.org/10.2307/3177638

Pussyhat Project. (n.d.). Our Story. Available at: https://www.pussyhatproject.com/our-story/ (Accessed July 2, 2018)

Radcliffe, S. (1998). Frontiers and popular nationhood: geographies of identity in the 1995 Ecuador-Peru border dispute. Political Geography, 17, 273-293. https://doi.org/10.1016/S0962-6298(96)00085-6

Riley, N. S. (July 2016). One Way to Help Native Americans: Property Rights," The Atlantic website. Available at: https:/ /www.theatlantic.com/politics/archive/2016/07/Native-americans-property-rights/492941/ (Accessed January 30, 2018)

Segal, C. (April 2017). Stitch by Stitch, a Brief History of Knitting and Activism. Available at: https:/ /www.pbs.org/newshour/arts/stitch-stitch-history-knitting-activism (Accessed July 6, 2018)

Serano, J. (2013). Excluded: Making Feminist and Queer Movements More Inclusive. Berkeley, CA: Seal Press.

Shiva, V. (1989). Staying Alive: Women, Ecology and Development. London: Zed Books.

Smith, A. (2005). Conquest: Sexual Violence and American Indian Genocide, New York, NY: South End Press.

Spivak, G. and Rooney, E. (1993). In a Word: Interview. In Outside in the Teaching Machine, 1-24. New York, NY: Routledge.

Steans, J. (2013). Gender and International Relations, 3rd Edition. Cambridge, UK: Polity Press.

Strathern, M. (2016). Before and After Gender: Sexual Mythologies of Everyday Life. Chicago: HAU Books. https://doi.org/10.14318/hau6.3.027

Tenreyro, T. (January 2017). White Women, You Can Do Better. Huffington Post website. Available at: https://www.huffingtonpost.com/entry/white-women-you-can-do-better_us_58877b68e4b08f5134b624b0 (Accessed January 30, 2018)

UN General Assembly. (1948). Universal Declaration of Human Rights (217 [III] A). Paris.

Wilson, P. and Stewart, M. eds. (2008). Global Indigenous Media: Cultures, Poetics and Politics. Durham: Duke University Press. https://doi.org/10.1215/9780822388692 